\title{
Creating bespoke note by note dishes and drinks inspired by traditional foods
}

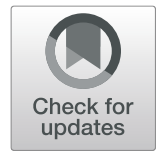

\author{
Róisín M. Burke ${ }^{*}$, Pauline Danaher and David Hurley
}

\begin{abstract}
French physical chemist, Hervé This, first proposed Note by Note (NbN) cooking in 1994. It is an application of molecular gastronomy and involves the use of compounds, either pure or in mixtures, rather than traditional food ingredients to make dishes. A review of international activities, relating to $\mathrm{NbN}$ cooking and cuisine, reveals that it has the potential to contribute to the creation of bespoke foods and drinks, e.g., by using ingredients which are sustainable and which provide nutritional value. However the 'food neophobia' of some consumers needs to be overcome to ensure its success. In light of these findings, it was decided to explore if and how the factors of food neophobia, sustainability and nourishment influenced students when they were developing their NbN dishes/drinks for their module assignment in TU Dublin. One hundred and five students at TU Dublin have, since 2013, completed NbN assignments and their corresponding reports which provide details of the development of their dishes/drinks. Eighty-seven of these were available for analysis. It was found that the majority of the students (62\%) were inspired by traditional foods to create bespoke NbN dishes/drinks, helping to address the 'food neophobia' of some consumers. The development of one of these dishes and one of these drinks is discussed. This information would be beneficial for others who will be developing NbN dishes/drinks.
\end{abstract}

Keywords: Note by note cooking, Traditional foods, Molecular gastronomy application

\section{Introduction}

\section{Molecular gastronomy}

In 1988, the scientific discipline called molecular gastronomy (MG) was created by Hervé This and Nicholas Kurti [16]. They decided to make MG a particular discipline because they realized that there was a growing gap between food science and home cooking [15]. Food science is concerned, in large measure, with food production on an industrial scale as well as nutrition and food safety. MG is concerned principally with the science behind any conceivable food preparation technique, that is used in a restaurant environment or even in domestic cooking, and produces the best possible result from readily available ingredients [4]. The main objective of MG is the discovery of new phenomena and new mechanisms [16].

\footnotetext{
* Correspondence: roisin.burke@tudublin.ie

School of Culinary Arts and Food Technology, TU Dublin, City Campus, Dublin 1, Ireland
}

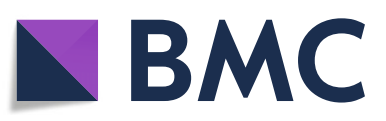

Applications building on the principles of MG, such as 'Molecular Cooking' and 'Note-by-Note cooking', have emerged in recent years [5].

\section{Note by note cooking and cuisine}

In the NbN cooking method, food ingredients such as meat, fish, vegetables or fruits are not used to make dishes, but instead compounds, either pure or in mixtures, are used. An analogy would be in the way that electronic music is not made using trumpets or violins but using pure waves that are mixed into sounds and music $[17,18]$. There are many aspects to consider in the design of the dish, including shape, consistency, nutritional properties, colour, odour, taste, trigeminal sensations and temperature [17]. Examples of pure compounds which may be used include 1-Octen-3-ol, which has a scent of wild mushrooms; limonene, a colourless liquid hydrocarbon that has the smell of citrus; sotolon, whose fragrance at high concentrations resembles curry and at low concentrations, maple syrup or

(c) The Author(s). 2020 Open Access This article is licensed under a Creative Commons Attribution 4.0 International License, which permits use, sharing, adaptation, distribution and reproduction in any medium or format, as long as you give appropriate credit to the original author(s) and the source, provide a link to the Creative Commons licence, and indicate if changes were made. The images or other third party material in this article are included in the article's Creative Commons licence, unless indicated otherwise in a credit line to the material. If material is not included in the article's Creative Commons licence and your intended use is not permitted by statutory regulation or exceeds the permitted use, you will need to obtain permission directly from the copyright holder. To view a copy of this licence, visit http://creativecommons.org/licenses/by/4.0/. 
sugar; and tyrosine, an odourless but flavourful amino acid present in cheese [18].

In the forthcoming book, Handbook of Molecular Gastronomy: Scientific Foundations and Culinary Applications, due to be published in 2021, Hervé This, in a chapter on $\mathrm{NbN}$ cooking and cuisine, discusses its history and charts its progress since 2009. He details how the pioneering French chef, Pierre Gagnaire, showed the first $\mathrm{NbN}$ dish to the international press in 2009 and how since then, $\mathrm{NbN}$ cooking has developed around the world. Chefs who have created NbN dishes and meals include those in Denmark (who prepared a $\mathrm{NbN}$ meal for the King's family), Japan ( $\mathrm{NbN}$ sushis were created by the chef Guillaume Siegler), Poland (Andrea Camastra of the Senses restaurant in Warsaw), Alsace in France (Julien Binz in his restaurant in Ammerschwihr), chefs from the Ecole Le Monde in Athens, Greece, and chefs from the At-Sunrise Global Chef Academy in Singapore created NbN dinners.

Hervé This has stated that $\mathrm{NbN}$ cooking promises to add unadulterated nutritional value to dishes of all kinds, actually improving upon the health benefits of so-called natural foods. He says that 'cooking with molecular compounds will be far more energy efficient and environmentally sustainable than traditional techniques of cooking' [18]. In the aforementioned Handbook of Molecular Gastronomy: Scientific Foundations and Culinary Applications, he says that 'projects for "sustainable food without waste" should become more and more important in the future and that there is a good argument for $\mathrm{NbN}$ to play a part in this direction, by the food industry and by domestic cooks'. However he emphasizes that $\mathrm{NbN}$ cuisine will succeed only if we tackle 'food neophobia' of the human species [17]. Pliner and Hobden [13] define food neophobia as the unwillingness or refusal to eat or the tendency to avoid new foods. In 2012, Hervé This, during a series of lectures and press conferences on $\mathrm{NbN}$ cooking organized at the Institut du Tourisme et d'Hôtellerie du Québec (ITHQ), observed that when the flavours of $\mathrm{NbN}$ dishes were more familiar, no rejection was observed by the journalists who were present.

Following this review of the current literature, 'food neophobia', nutrition and sustainability were found to be important factors for the development of $\mathrm{NbN}$ dishes and drinks. Therefore, a detailed analysis was conducted to examine if any of these factors influenced the $\mathrm{NbN}$ dishes/drinks which were developed by students in TU Dublin for their module assignment. The findings from the analysis will be beneficial for others who will be developing $\mathrm{NbN}$ dishes and drinks.

One hundred and five $\mathrm{NbN}$ dishes/drinks have been developed at TU Dublin (School of Culinary Arts and Food Technology) since 2013. Eighty-seven completed NbN assignments (2014-2020 incl.), and corresponding reports were available for analysis.

\section{Discussion}

Turning the unfamiliar into the familiar: making $\mathrm{NbN}$ foods and drinks more familiar by linking them with traditional foods and drinks

An analysis of $87 \mathrm{NbN}$ student project reports (20142020 incl.) showed that the majority 62\% (54) were inspired by traditional foods when creating their $\mathrm{NbN}$ dishes/drinks. The other 38\% (33) of dishes/drinks were developed around abstract themes (Fig. 1). Hervé This [17] has stated that it would be uninteresting to reproduce already existing food ingredients and that there is probably no value in making what already exists. He further emphasises that it is much more exciting to investigate flavours and dishes that were never envisioned using traditional food ingredients. The students did not re-create what already exists but were able to link $\mathrm{NbN}$ dishes/drinks with traditional foods to create bespoke foods. In this way perhaps, they were turning the unfamiliar to the familiar, by using social representations to enable themselves and potential consumers to come to terms with the new and unknown ([12] cited in [3]). Familiarity of food may be a central determinant of liking, especially for food-neophobic persons ([14] cited in [3]).

\section{Ethnicity and types of traditional foods and drinks which} inspired the $\mathrm{NbN}$ dishes/drinks

It was found that most students were influenced by traditional foods from America, followed by Britain, Italy, France, Mixes of Cuisines (from different countries to create one dish with different elements), Ireland, Puerto Rico, Asia, Canada, Germany, India, Russia, Spain and Singapore (Fig. 2). The students who developed the NbN

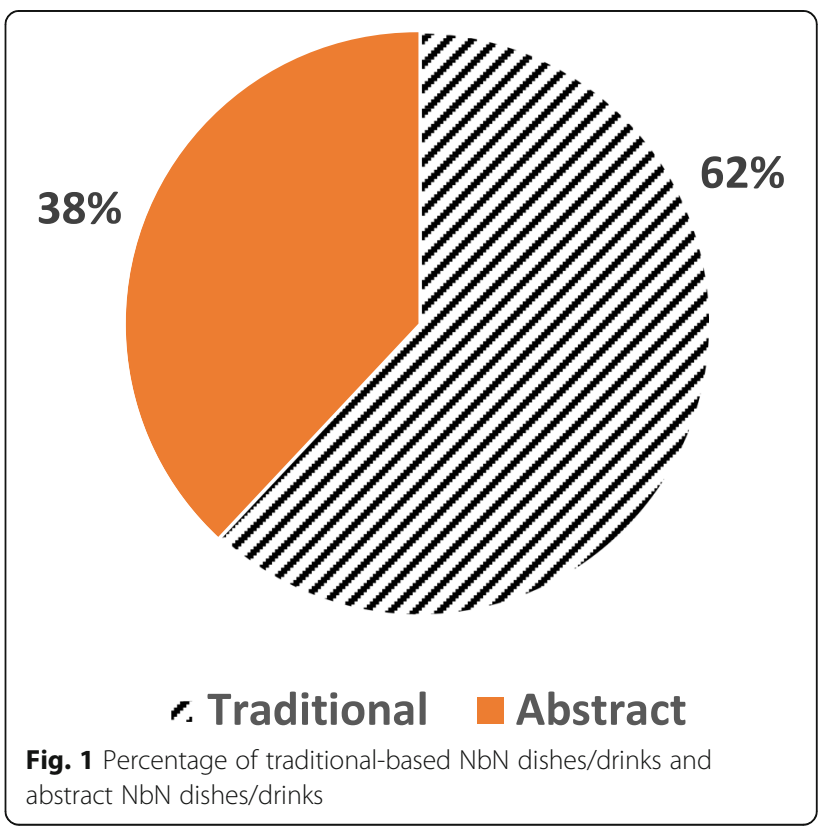




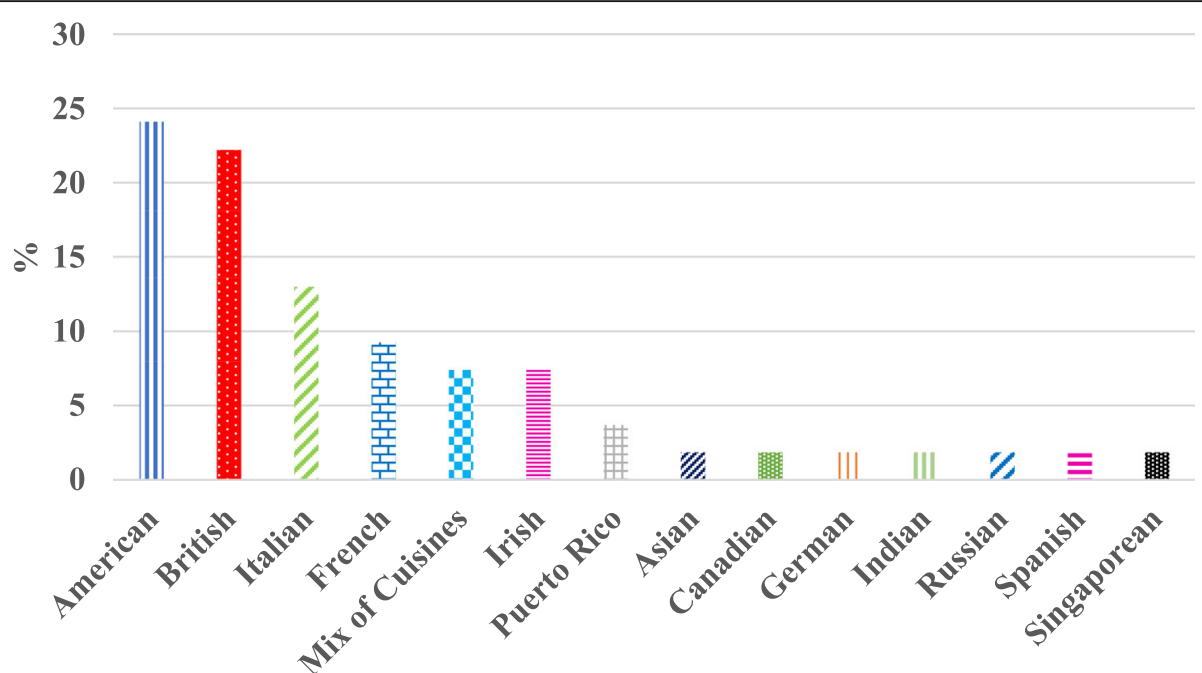

Ethnicity of dish/drink

Fig. 2 Ethnicity of chosen NbN dishes/drinks presented as a percentage of the total

dishes/drinks were mainly Irish (81\%), one was Russian, but had grown up in Ireland, and the remaining students were from Canada, China, England, France, Greece, India, Italy, Mexico and The Netherlands (one each). The nationality of the student sometimes influenced their choice of recipe, e.g., an Italian student chose a recipe idea from the cuisine of southern Italy and a Canadian student created a recipe which incorporated flavours associated with maple syrup. However, in most cases, the student was not influenced by their own nationality. The data shows that despite the majority of students being Irish, there was quite a variety of ethnic influences linked to their choice of $\mathrm{NbN}$ dishes/drinks (Figs. 2 and 3). This may be due to the culinary skills and knowledge of many of the students, gastronomic experiences while travelling abroad, and influences from media sources such as food networks and television shows, blogs and celebrity chefs.

$\mathrm{NbN}$ recipes were associated with traditional desserts or savoury dishes as well as traditional drinks including tea and alcoholic cocktails (Fig. 3). The most popular dessert foods were inspired by cheesecake (4), ice-cream (in 4 recipes), lemon meringue (2), carrot cake (2) and chocolate mousse (2). Examples of savoury-based $\mathrm{NbN}$ dishes included those associated with an Irish breakfast and with pizza while some drink recipes were influenced by a bloody Mary and a pina colada ( 2 each).

\section{Linking $\mathrm{NbN}$ dishes/drinks with traditional foods and drinks}

A detailed examination of the 87 student $\mathrm{NbN}$ assignment reports, for the use of the word 'traditional', was carried out using the word frequency application of NVivo 12. Sometimes, the word 'traditional' was used from secondary sources when citing from the literature.
These references were not examined any further but instead, those that were used by the student themselves in relation to their own work were. Table 1 highlights the use of the word 'traditional' or 'traditionally' by 18 of the 54 students, some of whom used the word more than once and in different contexts.

The analysis in Table 1 revealed that there were a number of different approaches that the students used to link their $\mathrm{NbN}$ dishes/drinks with traditional foods/ drinks. In total, there were twenty seven mentions of traditional, 12 were in the context of recipes, which represents $44 \%$ of the total, method (19\%), flavour, taste and meal ( $7 \%$ each) and process, ingredients, colour, and form at $4 \%$ each. The majority of students wrote about traditional recipes and how their $\mathrm{NbN}$ recipe was inspired by them. For example, there were references to a traditional meringue recipe, a traditional honeycomb recipe and a traditional dip. References to methods included infusion of oils, setting agents such as pectin, garnish methods such as julienne strips, and traditional cookery methods. Sensory properties associated with traditional dishes and drinks were adapted to $\mathrm{NbN}$ dishes and drinks. They included spicy flavour compounds which are sensed by the trigeminal nerves, for example those that would be familiar in Asian foods such as chilli flavours and the Tabasco flavours in a bloody Mary cocktail. Other sensory properties such as taste (sweet, savoury), colour (e.g., that associated with beetroot) and visual form (bread/cracker/chip) were linked to traditional foods and drinks.

- Other $\mathrm{NbN}$ meals were inspired by breakfast dishes such as the traditional full Irish breakfast and the traditional Singaporean breakfast dish Kaya (coconut 


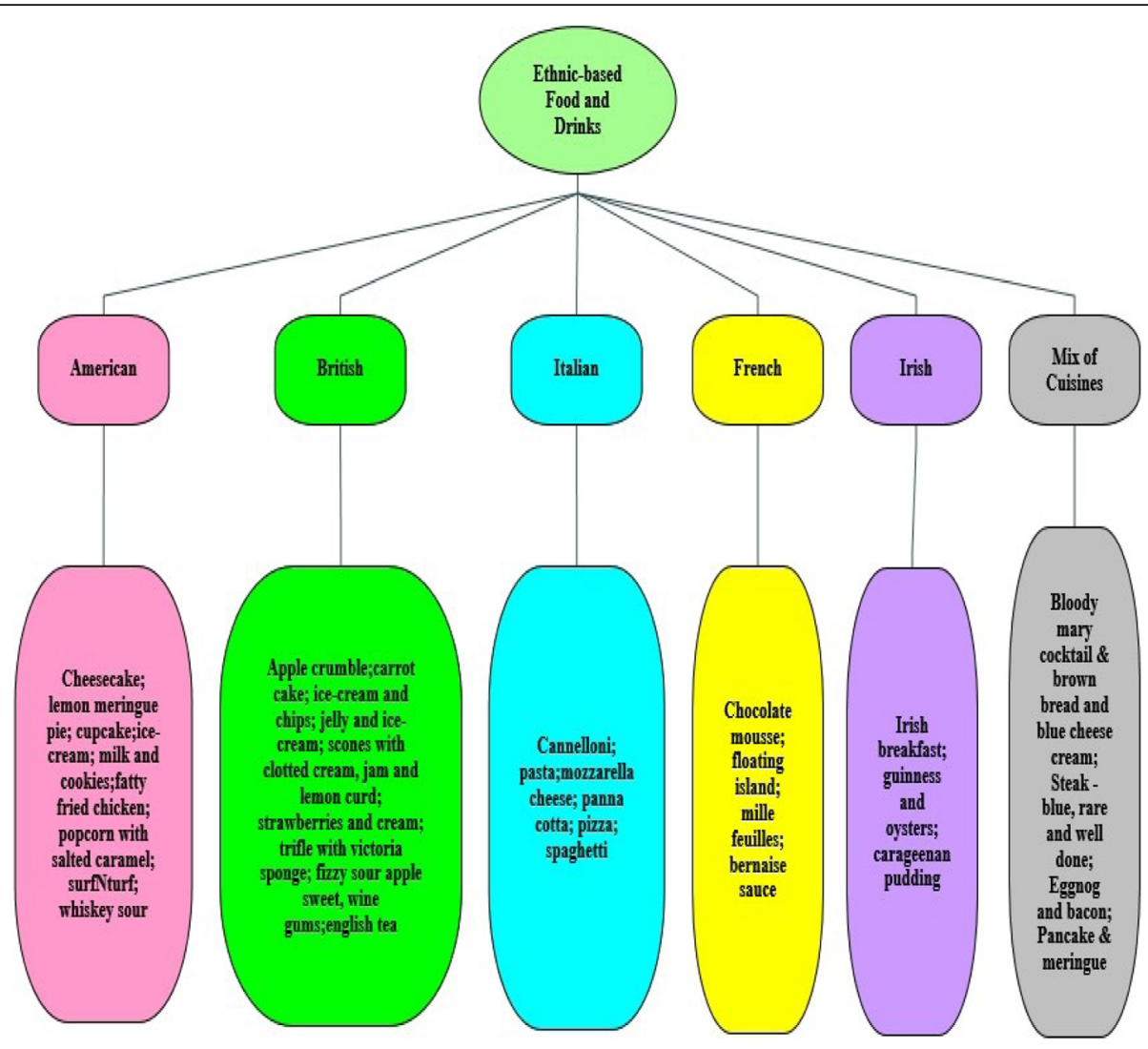

Fig. 3 Types of traditional food and drinks from the most popular ethnic cuisines

curd) on toast. Kaya is basically a bread spread. It is best described as a coconut egg jam which is used in the same way as peanut butter, strawberry jam or marmalade [6]. In the case of an Irish breakfast, there are many variations but according to Discovering Ireland [7] the basics include meats such as loin bacon or rashers, local sausages, black and white puddings (which are a type of sausage made up of pork meat, oats and spices and pork blood (in the black pudding)), eggs, mushrooms, tomatoes and cold cooked potato or potato bread (optional).

\section{The development of a bespoke $\mathrm{NbN}$ dish and a bespoke NbN drink}

A recent example which demonstrates how the development of $\mathrm{NbN}$ recipes is influenced by the taste and conformation of traditional foods is detailed below. Key elements of the recipes were the inclusion of ingredients which were from sustainable sources and which provided nutritional value. The dish and cocktail achieved joint first place in 2019, in the student category, when the theme of the Annual International NbN Contest (which is held in Paris, France) was "Diracs'and Cocktails'. According to Hervé This [1] for the particular content of this contest, it does not seem necessary to explain what a cocktail is; however, 'Diracs' are systems with the same type of nutritional properties of muscle tissue (meat, fish), but they are much more varied and can be designed to contain emulsions, fibres and lamellae with chosen colours, flavours and aromas. They are named in honour of the British theoretical physicist, Paul Dirac (1902-1984).

Competitors (in the three categories: chefs, students, amateurs) were invited to create 'Diracs' and/or cocktails. The TU Dublin prize winning 'Dirac' dish (which was composed of beetroot protein cake, horseradish jelly and beetroot cremeaux) and $\mathrm{NbN}$ eggnog cocktail are discussed here.

The main NbN dish (the 'Dirac') was modelled on the structure of meat muscle which is made of fibres, bound together with connective tissue, that are mainly linked to other groups of muscles or directly to the animal's bone structure. Muscle contains $60-70 \%$ moisture, $10-20 \%$ protein, $2-22 \%$ fat, and $1 \%$ ash, depending on type and species [2].

This [19] in his blog explains that in order to choose the right consistency (not too hard, not too soft), one has to experiment with water and protein concentrations, finally customising the colour, odour and taste before cooking. There were no meat proteins in the 'Dirac' 
Table 1 Frequency and context of use of the word 'Traditional'

\begin{tabular}{|c|c|c|}
\hline Student & Phrase & Context \\
\hline 1 & $\begin{array}{l}\text { The main flavour combination for this dish was chosen from a traditional Asian flavour combination } \\
\text { of chilli, garlic and ginger'. }\end{array}$ & Flavour \\
\hline 2 & 'The main element is inspired by the traditional "Bloody Mary" drink; a spicy vodka and tomato flavoured cocktail,' & Flavour \\
\hline 3 & 'Therefore it was decided to experiment with the traditional recipe for a meringue,' & Recipe \\
\hline 4 & 'Unlike the presence of custard in a traditional crème brulee which allowed for sugar to sit on the top layer' & Recipe \\
\hline 4 & 'This reflected the traditional food combination of carrots and potatoes'. & Recipe \\
\hline 5 & 'The idea of making this dish was inspired by some traditional dishes of the South of Italy'. & Recipe \\
\hline 6 & 'The red wine consommé is garnished traditionally with a julienne of pancake (Celestine garnish)' & Method \\
\hline 6 & 'The inclusion of traditional cookery methods' & Method \\
\hline 6 & 'It is difficult to get away from traditional dishes when trying to come up with a unique dish.' & Recipe \\
\hline 7 & 'This is a modern approach to what is a traditional method of infusing oils'. & Method \\
\hline 8 & $\begin{array}{l}\text { 'Kaya comes from Malay-Chinese. Traditionally it is made using palm sugar which gives the coconut curd a } \\
\text { rich brown colour. A curd has a higher amount of egg than a traditional milk cream and more sugar (like } \\
\text { pastry cream) it is cooked and enriched with butter'. }\end{array}$ & Recipe \\
\hline 8 & $\begin{array}{l}\text { The toasted caramel gives the dish another dimension of the traditional breakfast dish Kaya (coconut curd) } \\
\text { on toast. Experiment with a traditional honeycomb recipe' }\end{array}$ & Recipe \\
\hline 9 & 'Traditionally jellies, jams and conserves are made using fruit like berries, oranges etc.' & Recipe \\
\hline 10 & 'There was a rise but not as stiff as a traditional meringue' & Recipe \\
\hline 11 & 'Traditional thickeners like flour typically require far larger amounts to do a similar job'. & Recipe \\
\hline 12 & $\begin{array}{l}\text { 'a meal that was traditionally concocted to prepare one for a full days heavy duty work on the farm on a } \\
\text { cold winter morning' }\end{array}$ & Meal \\
\hline 12 & 'traditional food preparation processes' & Process \\
\hline 12 & $\begin{array}{l}\text { 'a Note by Note dish that would sound traditional and familiar to the consumer, but offer the opposite: a } \\
\text { modernised version of an old-fashioned meal with a completely different flavour, structure, taste and aroma'. }\end{array}$ & Meal \\
\hline 13 & 'the role of traditional ingredients in the cooking procedure' & Ingredients \\
\hline 14 & 'To achieve crunch, a traditional honeycomb recipe was constructed consisting of sugar, glucose and bicarbonate of soda.' & Recipe \\
\hline 15. & 'the colour of traditional garden beetroot' & Colour \\
\hline 15. & 'The Eggnog, rather than a traditional sweet alcoholic milk punch' & Taste \\
\hline 15 & 'instead of it being a sweet cocktail as is traditional, it will be savoury' & Taste \\
\hline 16 & 'in the form of a traditional bread/cracker/chip.' & Form \\
\hline 17 & 'Prior to the 1900s pectin was exclusively used in the traditional manner, to make jams and jelly' & Method \\
\hline 18 & to giv'to a dish you would traditionally add vinegar or the juice of a citrus' fruit' & Recipe \\
\hline 18 & 'In traditional jam making' & Method \\
\hline
\end{tabular}

dish. The beetroot protein cake had a protein content calculated at $21.3 \%$. It contained whey protein, egg white protein, soya protein and gluten. The beetroot cremeaux contained whey protein, micellar casein protein and egg white protein. The total protein content was calculated to be $24.8 \%$

The 'Dirac' which was developed was a representative of a cross section of skeletal muscle and muscle fibres as displayed in Fig. 4a. It was presented in a glass dish similar to a petri dish, as if the sample was to be examined under a microscope, a metaphoric reference to the science associated with $\mathrm{NbN}$ cooking (Fig. 4b). There was also flavoured smoke added to a glass cloche or cover to include a smoked or barbecued aroma (Fig. 4c). The main dish included a $\mathrm{NbN}$ beetroot protein cake, horseradish jelly and beetroot cremeaux. Beets and horseradish are traditionally used to make Chrain which is a spicy relish. It is a traditional Russian accompaniment and can be found in any kosher deli, and in the kosher section of many grocery stores [11].

Eggnog came to the US colonies in the eighteenth century, where the drink was changed. The frothy beverage is traditionally made out of eggs, sugar and cream and often flavoured with nutmeg and spiked with alcohol. Instead of adding the heavily taxed brandy or wine, colonists added rum which was referred to as grog, and bartenders served it in small wooden mugs called noggins. The drink first became known as egg-n-grog and later as eggnog [10]. In the $\mathrm{NbN}$ version, the concept for the cocktail was 'Bacon and Eggnog', but with a surprise 


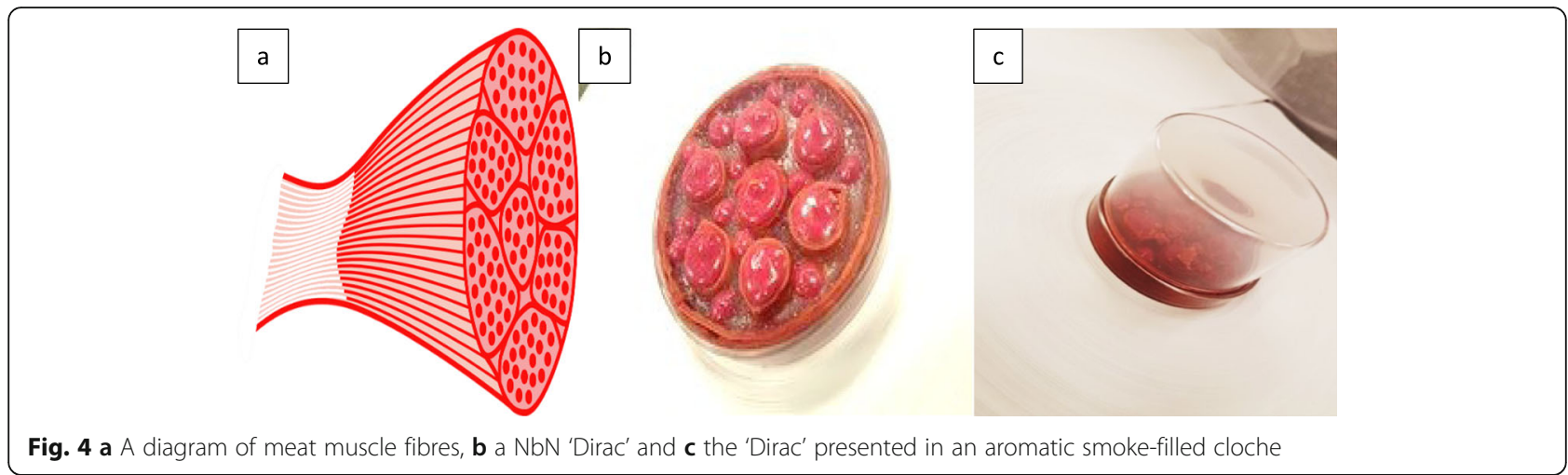

element. The 'Eggnog', rather than being a traditional sweet alcoholic milk punch [8], was designed to be a savoury drink with a bacon flavour. It contained micellar casein, whey protein and egg white protein. The final protein content was calculated to be $22.5 \%$. As with the $\mathrm{NbN}$ dish, it was also possible to customise the drink so that it was nutritional and contained sustainable ingredients.

Served alongside the $\mathrm{NbN}$ cocktail was what appeared to be a bacon crisp (Fig. 5). It provided texture, and rather than being savoury with a bacon flavour, it was a sweet crisp with vanilla flavour with a similar look to a dry crispy bacon cracker. Back bacon, which is the most common form of bacon in the UK (sometimes called Irish bacon or rasher or Canadian bacon) comes from the loin in the middle of the back of the pig. Back bacon has a more ham-like texture. The meat is cured-soaked in a solution of salt, nitrates and sometimes sugar-and often smoked before you cook it at home [20]. The bacon crisp contained rice protein, and the total protein content of the crisp was $7 \%$.

One student described their own dish (Table 1) as, 'a Note by Note dish that would sound traditional and familiar to the consumer, but offer the opposite: a modernised version of an old-fashioned meal with a completely different flavour, structure, taste and aroma'. In the case of the example which is detailed here, popular traditional foods were used as the inspiration for a $\mathrm{NbN}$ cocktail and dish. However as stated in Table 1, 'the eggnog instead of it being a sweet cocktail as is traditional, it will be savoury', the bacon was eggnog flavoured, and the popular Russian combination of horseradish and beetroot flavours of the 'Dirac' were married with the 'the colour of traditional garden beetroot' (Table 1) and the shape and form of meat muscle (Fig. 4a, b, c).

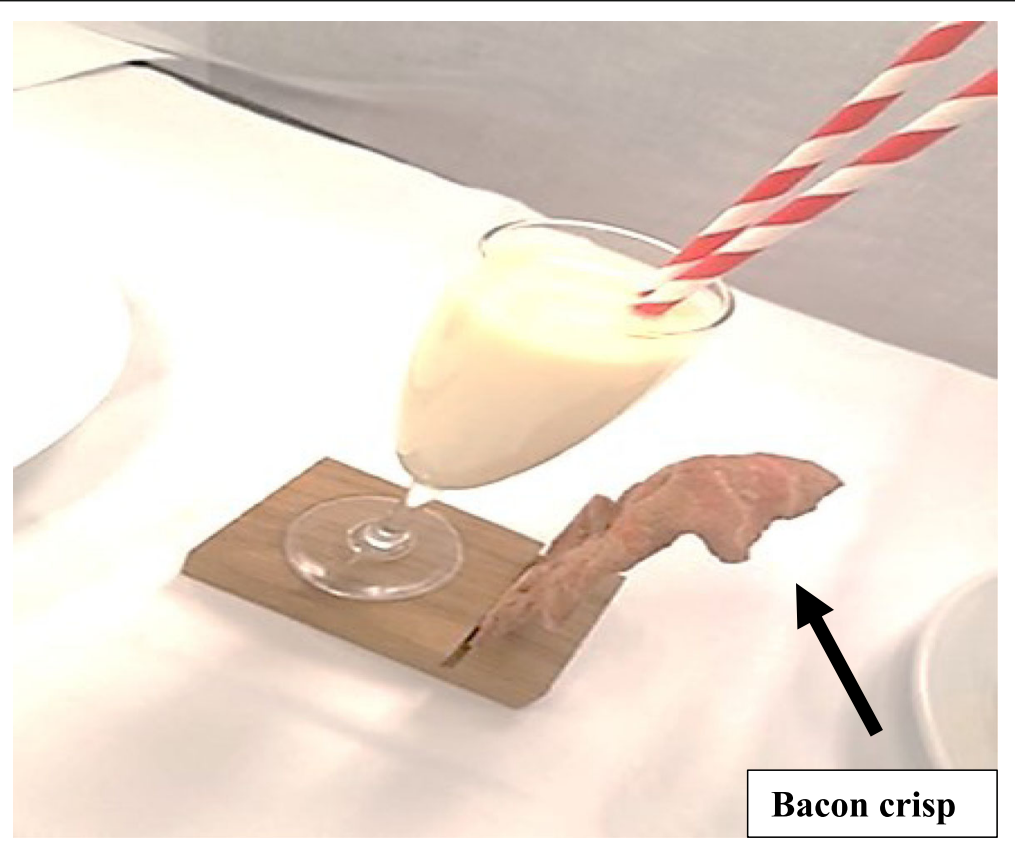

Fig. 5 Note by note eggnog with accompanying bacon crisp. Image: David Hurley (2019) [9] 


\section{Conclusion}

According to the literature, $\mathrm{NbN}$ cooking offers great potential to contribute to the development of sustainable and nutritious food, and the method can be used by chefs, consumers and food producers. For it to succeed, it must be accepted by the consumer. One way that may help to overcome a neophobic reaction is to make the $\mathrm{NbN}$ dish familiar to the consumer. A detailed analysis of 87 dishes/drinks which were produced by students from TU Dublin (Ireland) shows that the majority (62\%) of students achieved this through linking their recipes to traditional foods of varied ethnicities. This was achieved in different ways either through recipes, methods, flavours, tastes, meals, processes, ingredients, colours and form/shapes. It was possible to use ingredients from sustainable sources and to customise the nutritional composition, the physical and chemical properties, the sensory attributes and the conformation (shape and form). The inspiration from traditional foods will address the 'food neophobia' shown by some consumers contributing to the success of $\mathrm{NbN}$ cooking and cuisine.

\section{Acknowledgements}

The authors wish to thank La Rousse Foods Ireland who has sponsored student travel each year to the Annual International Note by Note Contest in Paris, France.

\section{Authors' contributions}

The first author planned, designed, analysed and wrote the study reported in this paper. The contribution of the second author was integral to the work which was reported in the study. The third author carried out experimental work reported in the study. The authors gave their permission for their contributions to be written and reported in the manuscript. The author(s) read and approved the final manuscript.

\section{Funding}

The study was carried out without funding

\section{Availability of data and materials}

All data referred to and discussed in the text was analysed and reported in this study.

\section{Competing interests}

The authors declare that they have no competing interests.

Received: 9 July 2020 Accepted: 3 September 2020

Published online: 16 September 2020

\section{References}

1. AgroParisTech. The announcement of the International Contest for Note by Note Cooking N². "Diracs and cocktails ». 2020. http://www2. agroparistech.fr/The-announcement-of-the-International-Contest-for-Noteby-Note-Cooking-No7. Accessed 16 May 2020

2. Anderson, W. (2012). Meat cutting and processing for food service. 2012 https://opentextbc.ca/meatcutting/chapter/composition-of-meat/ Accessed 29 Apr 2020

3. Bäckström A, Pirttilä-Backman AM, Tuorila H. Willingness to try new foods as predicted by social representations and attitude and trait scales. Appetite. 2004;43(1):75-83. https://doi.org/10.1016/j.appet.2004.03.004l.

4. Barham P, Skibsted LH, Bredie WLP, Bom Frøst M, Møller P, Risbo J, Mortensen LM. Molecular gastronomy: a new emerging scientific discipline. Chem Rev. 2010;110(4):2313-65. https://doi.org/10.1021/cr900105w.

5. Burke, R., This, H., and Kelly, A. L. Molecular gastronomy: an introduction. In Reference Module in Food Science. 2016. doi.https://doi.org/10.1016/B9780-08-100596-5.03384-9.
6. CNN. Where to find the best kaya toast in Singapore 2010. http://travel.cnn. com/singapore/eat/best-kaya-and-toast-singapore-970708/. Accessed 22 June 2020.

7. Discovering Ireland. The full Irish breakfast: the traditional Irish breakfast....a feast for a king or queen!. 2020. https://www.discoveringireland.com/thefull-irish-breakfast/. Accessed 22 June 2020.

8. Foodnetwork. Eggnog, 2020. http://www.foodnetwork.co.uk/recipes/ eggnog.html?utm_source=foodnetwork.com\&utm_medium=domestic. Accessed 22 June 2020.

9. Hurley, D. Note by note eggnog with accompanying bacon crisp. Own photograph. 2019

10. Lee, J. Christmas traditions explained: the eggnog. 2014. https://eu.usatoday com/story/news/nation-now/2014/12/22/christmas-traditions-explainedeggnog/19796657/ Accessed 16 May 2020.

11. Marmer, J. Chrain (Horseradish): enjoying a pungent Russian tradition. 2020 https://www.myjewishlearning.com/recipe/chrein-horseradish/ Accessed 16 May 2020.

12. Moscovici S. On social representations. In: Forgas JP, editor. Social cognition. Perspectives on everyday understanding. London: Academic Press; 1981. p. 181-209.

13. Pliner $P$, Hobden $K$. Developments of a scale to measure the trait of food neophobia in humans. Appetite. 1992:19:105-20.

14. Raudenbush B, Frank RA. Assessing food neophobia: the role of stimulus familiarity. Appetite. 1999:32:261-71.

15. This H. Molecular gastronomy. Angew Chem Int Ed. 2002;41(1):83-8. https:// doi.org/10.1002/1521-3773(20020104)41:1<83:.:AID-ANIE83>3.0.CO;2-F.

16. This H. Molecular gastronomy, a scientific look at cooking. Acc Chem Res. 2009:42(5):575-83.

17. This $\mathrm{H}$. Molecular gastronomy is a scientific discipline, and note by note cuisine is the next culinary trend. Flavour. 2013. https://doi.org/10.1186/ 2044-7248-2-1.

18. This H. Note-by-note cooking: the future of food. New York: Translated by Malcolm DeBevoise. Columbia University Press; 2014

19. This, Hervé. Diracs. Hervé This, vo Kientza: Atelier d'activités pratique note à note blog.[blog] 15 June. 2018. https://hervethis.blogspot.com/2018/06/ atelier-dactivites-pratique-note-note.html Accessed 29 May 292020

20. Trowbridge Filippone, P. What is bacon? Buying, cooking, and recipes. 2019. Available at: https://www.thespruceeats.com/what-is-bacon-p2-1806994 Accessed 16 May 2020.

\section{Publisher's Note}

Springer Nature remains neutral with regard to jurisdictional claims in published maps and institutional affiliations.

Ready to submit your research? Choose BMC and benefit from:

- fast, convenient online submission

- thorough peer review by experienced researchers in your field

- rapid publication on acceptance

- support for research data, including large and complex data types

- gold Open Access which fosters wider collaboration and increased citations

- maximum visibility for your research: over $100 \mathrm{M}$ website views per year

At BMC, research is always in progress.

Learn more biomedcentral.com/submissions 